\title{
Isolation and characterisation of Staphylococcus aureus strains isolated from beef, sheep and chicken meat*
}

\author{
Haydar ÖZDEMIR ${ }^{1}$, Erhan KEYVAN ${ }^{2}$ \\ ${ }^{1}$ Ankara University, Faculty of Veterinary Medicine, Department of Food Hygiene and Technology, Ankara; ${ }^{2}$ Mehmet Akif Ersoy \\ University, Faculty of Veterinary Medicine, Department of Food Hygiene and Technology, Burdur, Turkey.
}

\begin{abstract}
Summary: The objective of this study was to evaluate the occurrence, enterotoxigenic properties and antibiotic resistance of Staphylococcus aureus in beef, sheep and chicken meat. For this purpose, 225 meat samples were obtained from different supermarkets in Ankara. Firstly, these samples were analysed phenotypically for coagulase-positive staphylococci and $S$. aureus. Then phenotypically determined $S$. aureus isolates were confirmed through PCR assay and investigated by multiplex PCR for enterotoxin genes and mecA gene. According to the analyses, $14.6 \%, 30.6 \%$ and $45.3 \%$ of the beef, sheep and chicken meat samples respectively were found to be contaminated with $S$. aureus. Eighty eight (77.1\%) out of 114 S. aureus isolates were determined as enterotoxigenic. Also, isolates contained newly described enterotoxin like genes. These results indicated that new types enterotoxin genes could be effective in establishing food intoxication. In this study, isolates were found resistant to one or more antibiotics. None of the $S$. aureus isolates contain mecA gene but some of them were identified as resistant to a group of antibiotics like oxacillin and cefoxitin, which are used in determining methicillin resistance. For public health and hygienic meat production HACCP and GMP systems should be implemented effectively.

Keywords: Enterotoxin, meat, mecA, PCR, Staphylococcus aureus.
\end{abstract}

\section{Sığır, koyun ve piliç etlerinden Staphylococcus aureus'un izolasyon ve karakterizasyonu}

Özet: Bu çalışma sığır, koyun ve piliç etlerinde Staphylococcus aureus'un bulunuşu, enterotoksijenik özellikleri ve antibiyotik dirençliliklerini saptamak amacıyla yapılmıştır. Bu amaçla, Ankara'daki farklı süpermarketlerden 225 adet et örneği alınmıştır. Alınan örnekler öncelikle koagulaz-pozitif stafilokoklar ve $S$. aureus yönünden analiz edilmiştir. Fenotipik testler sonucu $S$. aureus olarak belirlenen suşlar PCR tekniği ile doğrulanarak, multipleks PCR tekniği kullanılarak enterotoksin genleri ve mecA geni yönünden analiz edilmiştir. Analiz sonuçlarına göre sığır, koyun ve piliç eti örnekleri S. aureus ile sırasıyla \% 14.6, \% 30.6 ve \% 45.3 düzeyinde kontamine bulunmuştur. İzole edilen 114 adet $S$. aureus izolatından 88'inin (\% 77.1) enterotoksijenik özellikte olduğu tespit edilmiştir. İzolatların yeni tanımlanan enterotoksin genlerine sahip oldukları belirlenmiştir. Sonuçlar, yeni tanımlanan enterotoksin genlerinin gıda intoksikasyonlarında önemli olabileceğini ortaya koymaktadır. Bu çalışmada izolatlar bir veya daha fazla antibiyotiğe dirençli bulunmuştur. S. aureus izolatlarının hiçbirinde mecA geni saptanmamasına karşın, bazı izolatlar metisilin duyarlılı̆̆ının belirlenmesinde kullanılan, oxacillin ve cefoxitine dirençli bulunmuştur. Halk sağlığının korunması ve hijyenik et üretimi için HACCP ve GMP sistemlerinin etkin uygulanması önemlidir.

Anahtar sözcükler: Enterotoksin, et, mecA, PCR, Staphylococcus aureus.

\section{Introduction}

Staphylococcus aureus food poisoning is an intoxication caused by the ingestion of food containing staphylococcal enterotoxins (SEs), and is one of the most common food borne diseases in the world. The primary habitat of $S$. aureus is the nasal passage of humans and the skin and hair of warm blooded animals (12). This bacterium produces a variety of extracellular products. Many of these, including the staphylococcal enterotoxins, are virulence factors, which have been implicated in humans and animal diseases. Heat stability is one of the most important properties of SEs with regard to food safety (15). So far, 20 serologically distinct SEs have been identified. SEA, SEB, SEC, SED, SEE represent classical types, while SEG, SEH, SEI and SEJ are newly described enterotoxins called SE-like toxins (SEl) because of the absence of emetic activity $(14,16,32)$.

There have also been several investigations into the growth of $S$. aureus and the production of enterotoxins in contaminated meat and meat products (24, 26, 29). Contamination of foods by $S$. aureus may occur directly from infected food-producing animals or may result from

\footnotetext{
* This study was supported by scientific research projects of Ankara University (Project number: 12A3338002).
} 
poor hygiene during the production process or during retail and storage of foods, since humans may carry the microorganisms (31). Besides, antimicrobial resistance is a major public health concern worldwide, due to the persistent circulation of resistant strains of bacteria in the environment and the possible contamination of food. $S$. aureus has been reported to frequently show multiple antimicrobial resistance patterns $(10,18,32)$.

The aims of the present study were: i) to evaluate the occurrence of $S$. aureus in beef, sheep and chicken meat obtained in Ankara; ii) to characterise the isolated strains based on their enterotoxigenic properties and mecA gene; iii) to undertake antibiotic susceptibility tests.

\section{Materials and Methods}

Sample collection: Meat samples were collected monthly from randomly selected supermarkets in Ankara. Each month, 25 samples were collected and in total 225 samples of beef $(n=75)$, sheep $(n=75)$, and chicken meat $(\mathrm{n}=75)$ were analysed.

Isolation and identification of $S$. aureus: Isolation and identification of $S$. aureus were performed according to the EN ISO 6888-1 standard procedure of the International Organization for Standardization (7) using Baird-Parker Agar (Merck, 1.03785) supplemented with Egg Yolk Tellurite Emulsion (Merck, 1.05406). The plates were incubated under aerobic conditions at $35^{\circ} \mathrm{C}$ for 24-48 h. If present, 5 egg yolk reaction-positive and 5 egg yolk reaction-negative colonies were chosen from each sample for further identification. All suspect colonies were confirmed by the coagulase test on EDTA coagulase plasma (Merck 1.13306) within $24 \mathrm{~h}$ at $37^{\circ} \mathrm{C}$. Then, coagulase positive colonies were analysed with Gram-staining, catalase reaction, DNase, beta hemolysis tests, clumping factor (Staphylase test, Oxoid, DR0595) and anaerobic utilisation of mannitol. According to these results, positive colonies were evaluated phenotypically as $S$. aureus (7).

DNA extraction: Phenotypically determined $S$. aureus isolates were enriched in Brain Heart Infusion Broth (Oxoid, CM0225) at $37^{\circ} \mathrm{C}$ for $18-24 \mathrm{~h}$, centrifuged at $10,000 \mathrm{xg}(1 \mathrm{~min})$, resuspended in $180 \mu \mathrm{l} \mathrm{TE}$ buffer containing $7 \mu \mathrm{l}$ of lysostaphin (Sigma, L7386) and incubated $1 \mathrm{~h}$ at $37^{\circ} \mathrm{C}(1)$. Then, DNA was extracted with DNeasy Blood\&Tissue-Kit (Qiagen, 69506) according to the manufacturer instructions.

Confirmation of $S$. aureus isolates with PCR: Phenotypically determined $S$. aureus isolates were confirmed using PCR assay. Sequences have been published by Brakstad et al. (4) for nuc gene and by Monday and Bohach (21) for 16S rRNA gene. After optimisation of PCR, amplification were performed using a thermal cycler (Eppendorf, Mastercycler) with initial denaturation step for $4 \mathrm{~min}$ at $94^{\circ} \mathrm{C}, 35$ cycles of $94^{\circ} \mathrm{C}$ for $30 \mathrm{~s}, 57.5^{\circ} \mathrm{C}$ for $30 \mathrm{~s}, 72^{\circ} \mathrm{C}$ for $30 \mathrm{~s}$; and a final elongation at $72^{\circ} \mathrm{C}$ for $10 \mathrm{~min}$ (the same PCR conditions were used for detection of mecA and tst gene). PCR reaction mixtures were performed in a total volume of 25 $\mu \mathrm{l}$, containing $0.3 \mu \mathrm{l}$ nuc gene primer 1 and primer 2 , $0.3 \mu 116 S$ rRNA gene primer 1 and primer $2,0.5 \mu \mathrm{l}(10$ $\mathrm{mM}) \mathrm{dNTP}, 1.5 \mu \mathrm{l}(25 \mathrm{mM}) \mathrm{MgCl}_{2}, 2.5 \mu \mathrm{l} 10 x \mathrm{PCR}$ buffer, $0.2 \mu 1$ Taq DNA polymerase and $16.6 \mu 1$ aqua dest. Finally $2.5 \mu 1$ DNA template was added to each reaction tube. PCR products were resolved by agarose gel electrophoresis and visualised on a UV transilluminator.

Multiplex PCR for detection of Staphylococcal enterotoxin genes: Nucleotid sequences have been published by Mehrotra et al. (20) for sea, seb, sec, sed, see, tst and mecA gene, by Monday and Bohach (21) for sej and Jarraud et al. (8) for seg, seh and sei gene. We modified the multiplex PCR method as 3 sets to avoid incorrect primer annealing for the detection of enterotoxin genes of the isolates. Sets were designed to amplify as set 1: seb, see, seh, sei; set 2: sec, sej, sed and set 3: sea, seg genes (multiplex PCR conditions for set 1, initial denaturation step for $4 \mathrm{~min}$ at $94^{\circ} \mathrm{C}, 35$ cycles of $94^{\circ} \mathrm{C}$ for $30 \mathrm{~s}, 55^{\circ} \mathrm{C}$ for $30 \mathrm{~s}, 72^{\circ} \mathrm{C}$ for $30 \mathrm{~s}$ and a final elongation at $72^{\circ} \mathrm{C}$ for $10 \mathrm{~min}$ and for set 2 and set 3 included the same constituents as in set 1 except for set 2 annealing at $55^{\circ} \mathrm{C}$ and set 3 annealing at $64.6^{\circ} \mathrm{C}$ ). PCR reaction mixtures were performed in a total volume of $30 \mu \mathrm{l}$, containing $0.3 \mu \mathrm{l}$ enterotoxin genes primer 1 and primer 2, $0.5 \mu \mathrm{l}(10 \mathrm{mM}) \mathrm{dNTP}, 3.0 \mu \mathrm{l}(25 \mathrm{mM}) \mathrm{MgCl}_{2}$, $3.0 \mu 1$ 10xPCR buffer, $0.2 \mu \mathrm{l}$ Taq DNA polymerase and $20.0 \mu \mathrm{l}$ aqua dest. Finally $2.5 \mu \mathrm{l}$ DNA template was added to each reaction tube. PCR was performed by using thermal cycler (Eppendorf, Mastercycler). PCR products were resolved by agarose gel electrophoresis and visualised on a UV transilluminator. The primer sequences and anticipated sizes of PCR products were shown in Table 1.

Antibiotic susceptibility testing: Antibiotic susceptibility testing of $S$. aureus isolates was performed on Mueller-Hinton Agar (Oxoid, CM0337) by the disk diffusion method in accordance with Clinical Laboratory Standards Institute guidelines (33). The antimicrobial agents tested included cefoxitin $(30 \mu \mathrm{g})$, tetracycline $(30 \mu \mathrm{g}), \quad$ gentamycin $(10 \mu \mathrm{g}), \quad$ oxacillin $(1 \mu \mathrm{g})$, chloramphenicol $(30 \mu \mathrm{g})$, vancomycin $(30 \mu \mathrm{g})$, ampicillin $(10 \mu \mathrm{g})$, sulphamethoxazole-trimethoprim $(25 \mu \mathrm{g})$, and erythromycin $(15 \mu \mathrm{g})$.

Reference strains: $S$. aureus reference strains producing sea, seb, sec, sed, see, seg/sei, seh, sej, tst were kindly provided by Dr. Ömer Akineden (Dairy Sciences, Institute of Veterinary Food Sciences, JustusLiebig- University Giessen, Germany). S. aureus reference strains (ATCC 25923, ATCC 43300) were used from the department's strain collection. 
Table 1. Primers sequences and anticipated sizes of PCR products used in present study. Tablo 1. Çalışmada kullanılan primer sekansları ve PCR ürünlerinin beklenen aralığı.

\begin{tabular}{|c|c|c|c|}
\hline Gene & Primer Sekansı (5'-3') & (bp) & References \\
\hline nuc & $\begin{array}{l}\text { 1-GCGATTGATGGTGATACGGTT } \\
\text { 2-AGCCAAGCCTTGACGAACTAAAGC }\end{array}$ & 270 & 10 \\
\hline $16 S r R N A$ & $\begin{array}{l}\text { 1-GTAGGTGGCAAGCGTTATCC } \\
\text { 2-CGCACATCAGCGTCAG }\end{array}$ & 228 & 21 \\
\hline tst & $\begin{array}{l}\text { 1-ATGGCAGCATCAGCTTGATA } \\
\text { 2-TTTCCAATAACCACCCGTTT }\end{array}$ & 350 & 9 \\
\hline sea & $\begin{array}{l}\text { 1-GGTTATCAATGTGCGGGTGG } \\
\text { 2-CGGCACTTTTTTCTCTTCGG }\end{array}$ & 102 & 20 \\
\hline seg & $\begin{array}{l}\text { 1-AATTATGTGAATGCTCAACCCGATC } \\
\text { 2-CTTATATGGAACAAAAGGTACTAGTTC }\end{array}$ & 642 & 8 \\
\hline$s e b$ & $\begin{array}{l}\text { 1-GTATGGTGGTGTAACTGAGC } \\
\text { 2-CCAAATAGTGACGAGTTAGG }\end{array}$ & 164 & 20 \\
\hline see & $\begin{array}{l}\text { 1-AGGTTTTTTCACAGGTCATCC } \\
\text { 2-CTTTTTTTTCTTCGGTCAATC }\end{array}$ & 209 & 20 \\
\hline seh & $\begin{array}{l}\text { 1-CAATCACATCATATGCGAAAGCAG } \\
\text { 2-CATCTACCCAAACATTAGCACC }\end{array}$ & 376 & 8 \\
\hline sei & $\begin{array}{l}\text { 1-CTCAAGGTGATATTGGTGTAGG } \\
\text { 2-AAAAAACTTACAGGCAGTCCATCTC }\end{array}$ & 577 & 8 \\
\hline $\mathrm{sec}$ & $\begin{array}{l}\text { 1-AGATGAAGTAGTTGATGTGTATGG } \\
\text { 2-CACACTTTTAGAATCAACCG }\end{array}$ & 451 & 20 \\
\hline $\operatorname{sej}$ & $\begin{array}{l}\text { 1-CATCAGAACTGTTGTTCCGCTAG } \\
\text { 2-CTGAATTTTACCATCAAAGGTAC }\end{array}$ & 142 & 21 \\
\hline sed & $\begin{array}{l}\text { 1-CCAATAATAGGAGAAAATAAAAG } \\
\text { 2-ATTGGT ATT TTT TTT CGT TC }\end{array}$ & 278 & 20 \\
\hline mecA & $\begin{array}{l}\text { 1-ACTGCTATCCACCCTCAAAC } \\
\text { 2-CTGGTGAAGTTGTAATCTGG }\end{array}$ & 163 & 20 \\
\hline
\end{tabular}

Table 2. Occurrence of coagulase-positive staphylococci and S. aureus in beef, sheep and chicken meat. Tablo 2. Sı ̆ıır, koyun ve piliç etlerinde koagulaz-pozitif stafilokoklar ve $S$. aureus'un bulunuşu.

\begin{tabular}{lcc}
\hline Sample & Coagulase-positive staphylococci & S. aureus \\
\hline & Number of positive samples/number analyzed & $\begin{array}{c}\text { Number of positive samples/number analyzed } \\
\text { (positive\%) }\end{array}$ \\
Beef & $13 / 75(17.3)$ & $11 / 75(14.6)$ \\
Sheep & $26 / 75(34.6)$ & $23 / 75(30.6)$ \\
Chicken & $41 / 75(54.6)$ & $34 / 75(45.3)$ \\
\hline
\end{tabular}

\section{Results}

In this study, within 146 coagulase-positive staphylococci (CPS) isolates, 114 of them were identified using classic culture methods as $S$. aureus. All of these $S$. aureus isolates were also confirmed by PCR assay (Figure 1). CPS were found in beef, sheep and chicken meat at levels of $17.3 \%, 34.6 \%, 54.6 \%$, respectively. The prevalence of $S$. aureus observed in this study was found in beef, sheep and chicken meat at levels of $14.6 \%$, $30.6 \%, 45.3 \%$, respectively (Table 2).

Out of 114 analysed S. aureus strains, 88 (77.1\%) were found to be enterotoxigenic (Table 3). Of the isolated enterotoxigenic strains $54(47.3 \%)$ contained sea, $10(8.7 \%)$ contained seh, $8(7.0 \%)$ contained sed + sej, $8(7.0 \%)$ contained tst, $4(3.5 \%)$ contained sei, 2 $(1.7 \%)$ contained sea+seh and $2(1.7 \%)$ contained sec + seg + sei+tst type enterotoxin genes (Figures 2 and 3 ) (Data not shown for set 3, mecA, tst gene). However, all $S$. aureus strains were negative for $s e b$ and see gene.

Table 3. Enterotoxigenic properties of S. aureus isolates. Tablo 3. S. aureus izolatlarının enterotoksijenik özellikleri.

\begin{tabular}{lc}
\hline Enterotoxin gene profiles & Number of isolates $(\%)$ \\
\hline Sea & $54(47.3)$ \\
seh & $10(8.7)$ \\
sed + sej & $8(7.0)$ \\
tst & $8(7.0)$ \\
sei & $4(3.5)$ \\
sea + seh & $2(1.7)$ \\
sec + seg+sei+tst & $2(1.7)$ \\
Total & $88(77.1)$ \\
\hline
\end{tabular}




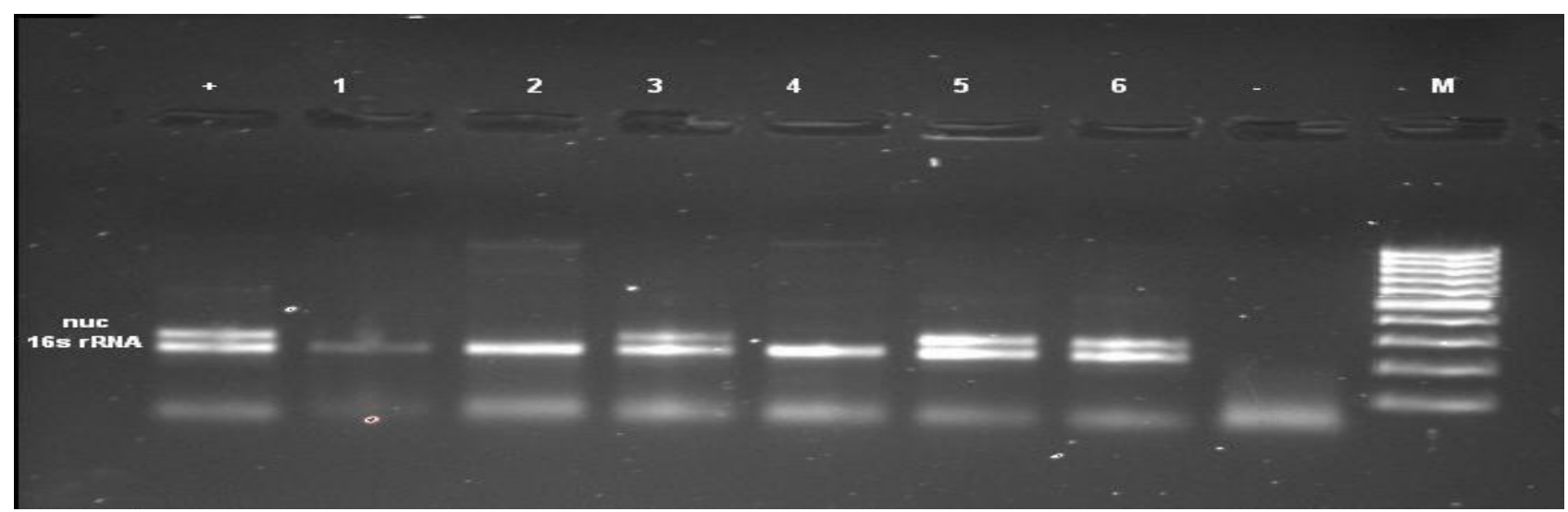

Figure 1. Confirmation of $S$. aureus isolates with nuc and $16 S$ rRNA genes. M: marker; +: positive controls; - and 1: negative control; 2, 3, 4, 5, 6: 16S rRNA gene positive samples; 3, 5, 6: nuc gene positive samples.

Şekil 1. S. aureus izolatlarının nuc ve $16 S$ rRNA genleri ile doğrulanması. M: marker; +: pozitif kontrol; - ve 1: negatif kontrol; 2, 3, 4, 5, 6: $16 S$ rRNA geni pozitif örnekler; 3, 5, 6: nuc geni pozitif örnekler.

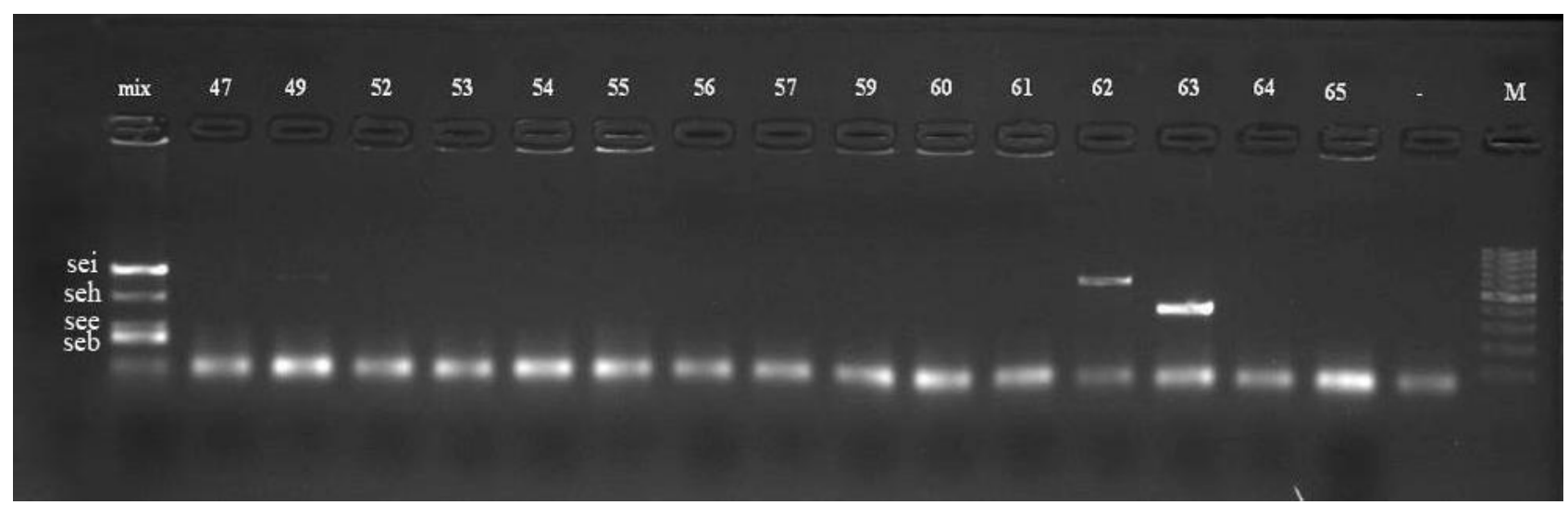

Figure 2. Agarose gel electrophoresis of Set 1 (seb, see, seh, sei) PCR products amplified with the multiplex PCR method. M: marker, Mix: DNA mixture of positive controls; -: Negative control; 62: sei positive sample; 63: seh positive sample.

Şekil 2. Multipleks PCR tekniği ile amplifikasyonu yapılan Set 1'deki (seb, see, seh, sei) PCR ürünlerin agaroz jel elektroforozis görüntüsü. M: marker, Miks: pozitif kontrollerin DNA miksi; -: negatif kontrol; 62: sei pozitif örnek; 63: seh pozitif örnek.

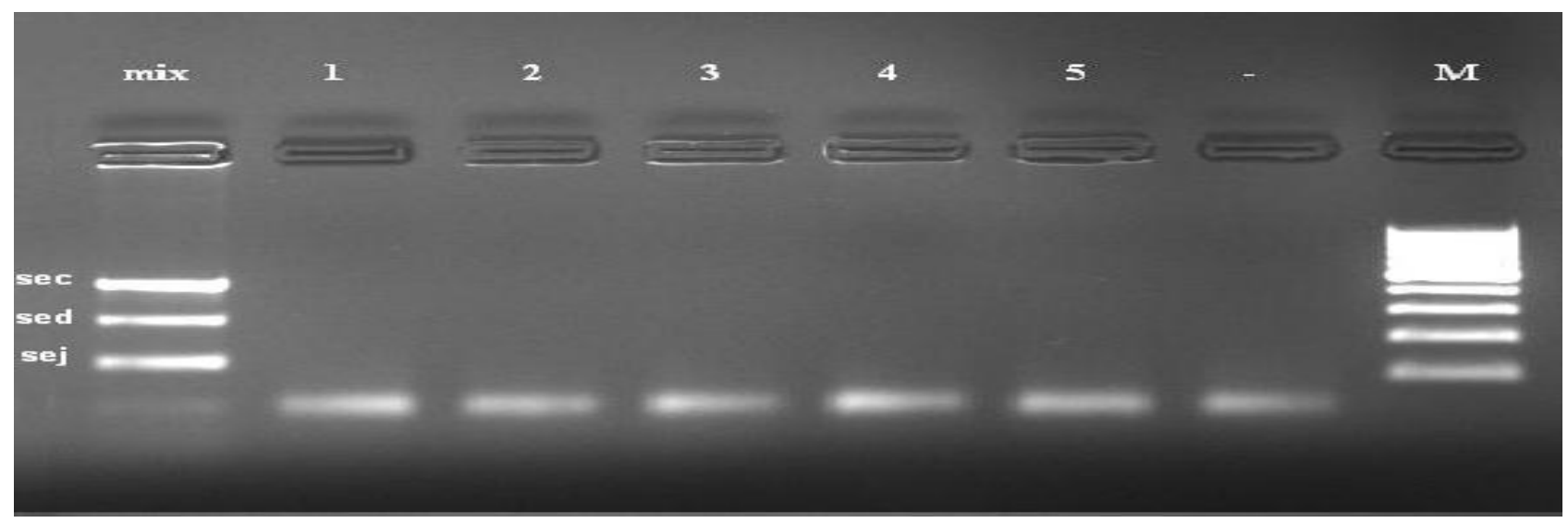

Figure 3. Agarose gel electrophoresis of Set 2 ( $\mathrm{sec}$, sed, sej) PCR products amplified with the multiplex PCR method. M: marker, Mix: DNA mixture of positive controls; -: Negative control; 1, 2, 3, 4, 5: sec, sed and sej gene negative samples.

Şekil 3. Multipleks PCR tekniği ile amplifikasyonu yapılan Set 2'deki (sec, sed, sej) PCR ürünlerin agaroz jel elektroforozis görüntüsü. M: marker, Miks: pozitif kontrollerin DNA miksi; -: negatif kontrol; 1, 2, 3, 4, 5: sec, sed, ve sej geni negatif örnekler. 
In this study, according to the disc diffusion test results, S. aureus isolates indicated high levels of resistance to ampicillin (70.1\%), tetracycline (47.3\%), erythromycin (33.3\%). In addition $S$. aureus isolates were resistant to cefoxitin $(22.8 \%)$, oxacillin $(15.7 \%)$, gentamicin (12.2\%), chloramphenicol (5.2\%), sulphamethoxazole-trimethoprim (3.5\%). All of the isolates were sensitive to vancomycin (Table 4).

Table 4. Antimicrobial resistance of $S$. aureus isolates. Tablo 4. S. aureus izolatlarının antimikrobiyal dirençliliğii.

\begin{tabular}{lc}
\hline \multicolumn{1}{c}{ Antibiotics } & $\begin{array}{c}\text { Number of resistant } \\
\text { isolates }(\%)\end{array}$ \\
\hline Amphicillin & $80(70.1)$ \\
Tetracycline & $54(47.3)$ \\
Erythromycin & $38(33.3)$ \\
Cefoxitin & $26(22.8)$ \\
Oxacillin & $18(15.7)$ \\
Gentamycin & $14(12.2)$ \\
Chloramphenicol & $6(5.2)$ \\
Sulphamethoxazole-trimethoprim & $4(3.5)$ \\
Vancomycin & $0(100)$ \\
\hline $\mathrm{n}=114$ &
\end{tabular}

\section{Discussion and Conclusion}

Occurrence of coagulase-positive staphylococci and S. aureus: In other comparative studies similar results were presented by Lim et al. (17) and Hanson et al. (6). Lim et al. (17) reported that, $9.7 \%$ of a total of 890 beef samples were contaminted with $S$. aureus. In addition, Hanson et al. (6) found that in the United States $6.9 \%$ of 29 beef samples were contaminated with $S$. aureus. However, our results are lower than those obtained by Kelman et al. (10) who reported that $29 \%$ of ground beef samples were contaminated with $S$. aureus. $\mathrm{Pu}$ et al. (29) reported that $20 \%$ of beef and beef products were contaminated with $S$. aureus. In this study 26 (34.6\%) of the 75 sheep meat samples were found coagulase-positive staphylococci. Other studies have reported coagulase-positive staphylococci at levels of $24.1 \%, 23.4 \%$ and $70 \%$ for sheep carcasses $(13,27,28)$. In this study, $S$. aureus was isolated from 34 (45.3\%) of 75 chicken meat samples. These results are similar to the $43.3 \%$ incidence reported by Lim et al. (17), but lower than the $65.8 \%$ value reported by Kitai et al. (11). In addition, Hanson et al. (6) found that in the United States, $17.8 \%$ of 45 chicken meat samples were contaminated with $S$. aureus. Other studies have reported levels of $S$. aureus at $23.8 \%$ and $22.5 \%$ for raw meat samples $(3,26)$.

$S$. aureus is generally found in the natural flora of animal and human skin and the human nasal passage. In addition, slaughterhouse hygiene, slaughtering techniques, storage, transport and general rules of hygiene are important factors in staphylococal contamination of beef, sheep and chicken meat.
However, sampling procedures (cotton swabbing, sponging, excising), sampling sites, sampling time and sampling at different slaughter process stages can also affect the results (5).

Enterotoxigenic properties of $S$. aureus isolates: Our results support previous research conclusions on the enterotoxin properties of $S$. aureus isolates $(2,24,25$, 30). In the present study, we observed that enterotoxigenic strains were relatively common among $S$. aureus isolates. In addition to the classical enterotoxin genes we also found SEl. This is at variance with other studies, which report that differences of the enterotoxigenic properties of $S$. aureus isolates are natural. Possible reasons for this situation arise from sample types, source of contaminations, bacteriologic culture methods, toxin production and detection methods.

All $114 S$. aureus strains analysed by PCR were negative for the mecA gene. Nitzsche et al. (23) similarly found that $S$. aureus isolates didn't have mecA gene. However, several investigations reported a few MRSA isolates $(3,11,15)$. Among the $S$. aureus isolates studied, various strains were found to be resistant to oxacillin and cefoxitin with disc diffusion tests but none of the isolates contained mecA gene by multiplex PCR. These results indicate that isolates may be a heteroresistant phenotype or carry amino acid substitutions in the transpeptidase domain of PBP2 which are responsible for the increased resistance $(19,22)$.

Antimicrobial resistance of $S$. aureus isolates: Antibiotic resistant $S$. aureus can be transmitted by food, including contaminated meat $(6,10,23,25,26)$. Also, investigators indicated that food was a good way to transmit antibiotic resistance to humans. In our study the S. aureus strains were found highly resistant to ampicillin and tetracycline. This is not surprising, because amphicillin and tetracyline are broad spectrum antibiotics that are commonly used for the treatment of infections in humans and animals. In comparisone with other studies, differences in the antibiotic resistance may arise from animal population, the inappropriate use of antibiotics for each infection and the use of antibiotics as a growth factor in animal feeding and to promote animal growth.

In this study, we found that $S$. aureus isolates from beef, sheep and chicken meat samples have heterogeneous enterotoxigenic properties and newly described enterotoxin genes. The results indicated that new types enterotoxin genes could be effective in food intoxication. Also, isolates were found resistant to one or more antibiotics. None of the $S$. aureus isolates contained $m e c A$ gene but some of them were identified as resistant to a group of antibiotics like oxacillin and cefoxitin which are used in determining methicillin resistance. Thus, for public health and hygienic meat production HACCP and GMP systems should be implemented effectively. 


\section{References}

1. Akineden O, Hassan AA, Schneider E, et al. (2008): Enterotoxigenic properties of Staphylococcus aureus isolated from goats 'milk cheese. Int J Food Microbiol, 124, 211-216.

2. Arcuri EF, Angelo FF, Guimarães MF, et al. (2010): Toxigenic status of Staphylococcus aureus isolated from bovine raw milk and Minas frescal cheese in Brazil. J Food Prot, 73, 2225-2231.

3. Bhargava K, Wang X, Donabedian S, et al. (2011): Methicillin-resistant Staphylococcus aureus in retail meat, Detroit, MI, USA. Emerg Infect Dis, 17, 1135-1137.

4. Brakstad OG, Aasbakk K, Maeland JA (1992): Detection of Staphylococcus aureus by polymerase chain reaction amplification of the nuc gene. J Clin Microbiol, 30, 1654-1660.

5. Gill CO, Badoni M, McGinnis JC (2001): Microbiological sampling of meat cuts and manufacturing beef by excision or swabbing. J Food Prot, 64, 325-334.

6. Hanson BM, Dressler AE, Harper AL, et al. (2011): Prevalence of Staphylococcus aureus and methicillinresistant Staphylococcus aureus (MRSA) on retail meat in Iowa. J Infec Public Health, 4, 169-174.

7. International Standard Office (2003): Microbiology of food and animal feeding stuffs - horizontal method for the enumeration of coagulase-positive staphylococci, EN ISO 6888-1 (Staphylococcus aureus and other species).

8. Jarraud S, Cozon G, Vandenesch F, et al. (1999): Involvement of enterotoxins $G$ and $I$ in staphylococcal toxic shock syndrome and staphylococcal scarlet fever. J Clin Microbiol, 37, 2446-2449.

9. Johnson, WM, Tyler SD, Ewan EP, et al. (1991): Detection of genes for enterotoxins, exfoliative toxins, and toxic shock syndrome toxin 1 in Staphylococcus aureus by the polymerase chain reaction. J Clin Microbiol, 29, 426-430.

10. Kelman A, Soong YA, Dupuy N, et al. (2011): Antimicrobial susceptibility of Staphylococcus aureus from retail ground meats. J Food Prot, 74, 1625-1629.

11. Kitai S, Shimizu A, Kawano J, et al. (2005): Characterization of methicillin-resistant $S$. aureus isolated from retail raw chicken meat in Japan. J Vet Med Sci, 67, 107-110.

12. Kluytmans J, Van Belkum A, Verbrugh H (1997): Nasal carriage of Staphylococcus aureus: Epidemiology, underlying mechanisms, and associated risks. Clin Microbiol Rev, 10, 505-520.

13. Koc HI, Ozdemir H (2013): Determination of microbial surface contamination on lamb carcasses. J Turk Vet Med Society, 84, 19-25.

14. Kuzma K, Malinowskie E, Lassa H, et al. (2003): Detection of genes for enterotoxins and toxic shock syndrome toxin-1 in Staphylococcus aureus isolated from bovine mastitis. Bull Vet Inst Pulawy, 47, 419-426.

15. Lee JH (2003): Methicillin (oxacillin)-resistant Staphylococcus aureus strains isolated from major food animals and their potential transmission to humans. Appl Environ Microbiol, 69, 6489-6494.

16. Le Loir Y, Baron F, Gautier M (2003): Staphylococcus aureus and food poisoning. Gen Mol Research, 2, 63-67.

17. Lim SK, Nam HM, Park HJ, et al. (2010): Prevalence and characterization of methicillin resistant Staphylococcus aureus in raw meat in Korea. J Microbiol Biotech, 20, 775-778.

18. Livermore DM (2000): Antibiotic resistance in staphylococci. Int J Antimicrobial Agents, 16, 3-10.
19. McCallum N, Berger-Bachi B, Senn MM (2010): Regulation of antibiotic resistance in Staphylococcus aureus. Int J Med Microbiol, 300, 118-129.

20. Mehrotra M, Wang G, Johnson WM (2000): Multiplex PCR for detection of genes for Staphylococcus aureus enterotoxins, exfoliative toxins, toxic shock syndrome toxin 1 and methicillin resistance. J Clin Microbiol, 38, 1032-1035.

21. Monday SR, Bohach GA (1999): Use of multiplex PCR to detect classical and newly described pyrogenic toxin genes in staphylococcal isolates. J Clin Microbiol, 37, 3411-3414.

22. Nadarajah J, Lee MJS, Louie L, et al. (2006): Identification of different clonal complexes and diverse amino acid substitutions in penicillin-binding protein 2 $(P B P 2)$ associated with borderline oxacillin resistance in Canadian Staphylococcus aureus isolates. J Med Microbiol, 55, 1675-1683.

23. Nitzsche S, Zweifel C, Stephan R (2007): Phenotypic and genotypic traits of Staphylococcus aureus strains isolated from pig carcasses. Vet Microbiol, 120, 292-299.

24. Normanno G, Corrente M, La Salandra G, et al. (2007): Occurrence, characterization and antimicrobial resistance of enterotoxigenic Staphylococcus aureus isolated from meat and dairy products. Int $\mathrm{J}$ Food Microbiol, 115, 290-296.

25. Pereira V, Lopes C, Castro A, et al. (2009): Characterization for enterotoxin production, virulence factors, and antibiotic susceptibility of Staphylococcus aureus isolates from various foods in Portugal. Food Microbiol, 26, 278-282.

26. Pesavento G, Ducci B, Comodo N, et al. (2007): Antimicrobial resistance profile of Staphylococcus aureus isolated from raw meat: A research for methicilin resistant Staphylococcus aureus (MRSA). Food Control, 18, 196-200.

27. Philips D, Jordan D, Morris S, et al. (2006): Microbiological quality of Australian sheep meat in 2004. Meat Sci, 74, 261-266.

28. Philips D, Sumner J, Alexander JF, et al. (2001): Microbiological quality of Australian sheep meat. J Food Prot, 64, 697-700.

29. Pu S, Han F, Ge B (2009): Isolation and characterization of methicillin-resistant Staphylococcus aureus strains from Louisiana retail meats. Appl Environ Microbiol, 75, 265-267.

30. Rosec JP, Gigaud O (2002): Staphylococcal enterotoxin genes of classical and new types detected by PCR in France. Int J Food Microbiol, 77, 61-70.

31. Seo SK, Bohach GA (2007): Staphylococcus aureus. 493 518. In: Doyle MP, Beuchat LR (Eds.), Food Microbiology. 3rd ed. ASM Press, Washington.

32. Stephan R, Annemuller C, Hassan AA, et al. (2001): Characterization of enterotoxigenic Staphylococcus aureus strains isolated from bovine mastitis in north-east Switzerland. Vet Microbiol, 78, 373-382.

33. The Clinical and Laboratory Standards Institute (CLSI) (2011): The Clinical and Laboratory Performance Standards for Antimicrobial Susceptibility Testing, $21^{\text {th }}$ Informational Supplement. M100-S21. Wayne Pa.

Geliş tarihi:06.07.2015 / Kabul tarihi:20.02.2016
Adress for correspondence:
Prof. Dr. Haydar OZDEMIR
Ankara University, Faculty of Veterinary Medicine,
Department of Food Hygiene and Technology,
Ankara, Turkey.
e-mail:hozdemir@veterinary.ankara.edu.tr 